\title{
Third Party Consent to Search and Seizure
}

Whenever two or more persons share a common residence and a police search authorized by one discloses evidence which incriminates another, a difficult question arises regarding admission of such evidence in criminal proceedings against the nonconsenting party. ${ }^{\perp}$ Although proper resolution of the third party consent problem raises significant questions concerning the nature of the protection afforded by the fourth amendment and the proper scope of the exceptions to the amendment's warrant requirement, ${ }^{2}$ the problem itself has received little critical examination. ${ }^{3}$ This comment undertakes such an examination with a view toward reconciling the individual's interest in remaining free from unwarranted governmental intrusions into his privacy with society's interest in maintaining order and punishing criminals. It is suggested here that both interests can be accommodated by disallowing searches undertaken on the basis of consent by a "third party" except in those cases when he is actually the agent of the non-

1 The most frequent cases involve a wife's consent that incriminates her husband. See, e.g., United States v. Pugliese, 155 F.2d 497 (2d Cir. 1945); United States v. Sergio, 21 F. Supp. 553 (E.D.N.Y. 1937); In re Lessard, 62 Cal. 2d 497, 399 P.2d 50, 42 Cal. Rptr. 583 (1965); State v. Evans, 45 Hawaii 622, 372 P.2d 365 (1962); People v. Perroni, 14 Ill. 2d 581, 153 N.E.2d 578 (1958); People v. Shambley, 4 Ill. 2d 38, 122 N.E.2d 172 (1954); Henry v. State, 154 So. 2d 289 (Miss. 1963); Simmons v. State, 94 Okla. Crim. 18, 229 P.2d 615 (1951). For cases involving the consent of one co-tenant incriminating another see, e.g., Stein v. United States, 166 F.2d 851 (9th Cir. 1948); Tompkins v. Superior Court, 59 Cal. 2d 65, 378 P.2d 113, 27 Cal. Rptr. 889 (1963); People v. Banks, 47 Cal. Rptr. 499 (Dist. Ct. App. 1965). A parent's consent to search may incriminate a resident child. E.g., Maxwell v. Stephens, 348 F.2d 325 (8th Cir. 1965), cert. denied, 382 U.S. 944 (1966); Irvin v. State, 66 So. 2d 288 (Fla. 1953); Morris v. Commonwealth, 306 Ky. 349, 208 S.W.2d 58 (1948); State v. Kindermann, 271 Minn. 408, 136 N.W.2d 577 (1965). For examples of a proprietor's consent to a search which incriminated his guests, see Fredericksen v. United States, 266 F.2d 463 (D.C. Cir. 1959); Woodward v. United States, 254 F.2d 312 (D.C. Cir.), cert. denied, 357 U.S. 930 (1958); Calhoun v. United States, 172 F.2d 457 (5th Cir. 1949); Idol v. State, 233 Ind. 307, 119 N.E.2d 428 (1954). For an instance in which an agent's consent to search incriminated his principal, see, e.g., United States v. Antonelli Fireworks Co., 155 F.2d 631 (2d Cir.), cert. denied, 329 U.S. 742 (1946).

2 See text accompanying notes 9-21 infra.

3 Two recent treatments of the problem are Note, 51 CoRNeLL L.Q. 795 (1966) and 79 HARv. L. REv. 1513 (1966). Also, several recent efforts have involved the specific problem of spousal consent. See Comment, The Effect of a Wife's Consent to a Search and Seizure of the Husband's Property, 69 Drck. L. REv. 69 (1964); Comment, The Use of Evidence Obtained During a Search and Seizure Consented to by the Defendant's Spouse, 1964 U. ILL. L.F. 653. 
consenting party and is empowered to authorize a search on the latter's behalf or when his interests in authorizing a particular search otherwise clearly dominate the nonconsenter's interest in privacy.

\section{The Conceptual Framework}

The aim of the fourth amendment's prohibition of unreasonable searches and seizures ${ }^{4}$ is to prevent unjustified official invasions of the privacy of individuals. ${ }^{5}$ To this end, the reasonableness requirement of the first clause of the fourth amendment has traditionally been read in conjunction with the warrant requirement of the amendment's second clause, which has afforded the needed referent from which the reasonableness of any search could be initially measured. ${ }^{6}$ A search not authorized by a search warrant is generally held to be unreasonable unless it falls within one of the well defined exceptions to the warrant requirement. ${ }^{\top}$ Thus, in its narrowest construction, the right protected by the fourth amendment is the right, absent exceptional circumstances, to be free from a warrantless intrusion by the police into one's privacy. ${ }^{8}$ The right is personal and extends to one's person, house, papers, and effects.

Exceptions to the warrant requirement have existed from an early date because the community's need for effective law enforcement has militated against the maintenance of an overly strict, prophylactic

4 "The right of the people to be secure in their persons, houses, papers, and effects, against unreasonable searches and seizures shall not be violated, and no Warrants shall issue, but upon probable cause supported by oath or affirmation, and particularly describing the place to be searched or things to be seized." U.S. ConsT. amend. IV.

5 See, e.g., Mapp v. Ohio, 367 U.S. 643 (1961); Wolf v. Colorado, 338 U.S. 25, 27 (1949); Boyd v. United States, 116 U.S. 616, 630 (1886). See generally Beaney, The Constitutional Right to Privacy in the Supreme Court, 1962 Sup. Cr. REv. 212; Kaplan, Search and Seizure: $A$ No Man's Land in the Criminal Law, 49 CALIF. L. REv. 474 (1961); Reynard, Freedom From Unreasonable Search and Seizure-A Second Class Right?, 25 IND. L.J. 259 (1950). See also text accompanying notes 57-66 infra.

6 See Mr. Justice Frankfurter's discussion of the historical gloss on the fourth amendment in his dissent in United States v. Rabinowitz, 339 U.S. 56, 68-86 (1950). Some commentators have suggested that Rabinowitz represented a marked departure from the general warrant requirement and established the "reasonableness" requirement, without reference to the warrant requirement, as the amendment's focal point. See Comment, Search and Seizure in the Supreme Court: Shadows on the Fourth Amendment, $28 \mathrm{U}$. CHr. L. REv. 664, 678-92 (1961). However, subsequent cases clearly indicate that the normal warrant requirement was not intended to be replaced and that Rabinowitz represented only an expansion of the exception to the warrant rule involving a search incident to a valid arrest. See, e.g., cases cited in note 7 infra.

7 See, e.g., Riòs v. United States, 364 U.S. 253, 261 (1960); Weaver v. United States, 295 F.2d 360 (5th Cir. 1961); United States v. Costner, 217 F. Supp. 644 (E.D. Tenn. 1963).

$8 \mathrm{~A}$ search may be held invalid even when supported by a valid warrant if the search is conducted in an unreasonable manner. See, e.g., Kremen v. United States, 353 U.S. 346 (1957); Mellet \& Nichter Brewing Co. v. United States, 296 Fed. 765 (E.D. Pa. 1923). 
protection. Undoubtedly, pressure for relaxation of the warrant requirement has been especially great since the introduction of the exclusionary rule, ${ }^{9}$ which, though arguably the only effective method by which fourth amendment rights can be protected, is a drastic solution, frequently resulting in freeing criminals in cases of unquestionable guilt. ${ }^{10}$ It is therefore not surprising that two of the major exceptions to the warrant requirement-the search incident to a valid arrest ${ }^{11}$ and the search of a motor vehicle when there is probable cause to believe that it contains the fruits or instrumentalities of crime $^{12}$ have, over the years, been consistently liberalized.

The rationales underlying these exceptions are highlighted by the tension between individual rights and the effective enforcement of the criminal law. Both exceptions are justified primarily by reason of their necessity. ${ }^{13}$ The sweeping scope of a permissible search incident to a valid arrest is also grounded, to some extent, on the usually unarticu-

9 The exclusionary rule, introduced in Weeks v. United States, 232 U.S. 383 (1914), applied only to federal proceedings until Mapp v. Ohio, 367 U.S. 643 (1961), which held the rule applicable to the states.

10 See Kaplan, supra note 5.

11 See, e.g., Draper v. United States, 358 U.S. 307 (1959); United States v. Rabinowitz, 339 U.S. 56 (1950); Harris v. United States, 331 U.S. 145 (1947). Where the arrest is merely a pretext to conduct a search, the search may be held illegal. See Jones v. United States, 357 U.S. 493 (1958); McKnight v. United States, 183 F.2d 977 (D.C. Cir. 1950); Worthington v. United States, 166 F.2d 557 (6th Cir. 1948); Henderson v. United States, 12 F.2d 528 (4th Cir. 1926).

12 Carroll v. United States, 267 U.S. 132, 158 (1925).

13 Searches incident to a valid arrest are justified by the need of the arresting officer to protect himself and the necessity of preventing both the escape of the arrestee and the destruction of evidence. Accordingly, a warrantless search of the arrestee, see, e.g., Draper v. United States, 358 U.S. 307 (1959); Blackford v. United States, 247 F.2d 745 (9th Cir.), cert. denied, 356 U.S. 914 (1957); Simms v. United States, 171 F. Supp. 834 (D.D.C. 1959), and the physical area under his immediate control, see, e.g., Carroll v. United States, 267 U.S. 132 (1925), are held to be proper. Recently, the permissible scope of a search incident to a valid arrest has been considerably broadened, and now includes the entire premises wherein the accused was arrested. Compare Cornelius, SEARCH AND SEIzURE 177-80 (2d ed. 1930), with Williams v. United States, 273 F.2d 781 (9th Cir. 1959). The present breadth of this exception is suggested by the following comment: "This exception today is so broad that in great part it swallows up the rule and it is safe to say that the numbers of searches which are upheld under this exception far exceed the number where a search warrant has been procured." Kaplan, supra note 5, at 490 . It is clear that the original rationale underlying the exception is inadequate to support the wide ranging searches undertaken today. For discussion of the need to reconcile fourth amendment theory with the practice of courts and the police see Comment, supra note 6, 28 U. CHr. L. REv. 664.

The warrantless search of a motor vehicle where there is probable cause to believe that it contains contraband rests on the recognition that in the time required to secure a warrant a mobile vehicle can disappear or move into a jurisdiction where the warrant would be unusable. Hence if there is to be any search at all it must be warrantless. 
lated notion that to require police to secure a warrant before searching a premises wherein an arrest is made would be a meaningless requirement, since a warrant in such cases would invariably issue as a matter of form. ${ }^{14}$

Consent to search and seizure, the third principal exception to the warrant requirement, ${ }^{15}$ is predicated on a different rationale. One's power to consent to a search stems from the long accepted rule that a person can intelligently and knowingly waive his right to be free from a warrantless police search. ${ }^{16}$ However, since the needs of the state are minimal where consent to search is sought ${ }^{17}$ and since such consent represents a waiver of a fundamental constitutional right, ${ }^{18}$ it is not surprising that courts have not only been quite unwilling to expand the consent exception, ${ }^{19}$ but have, in several cases, severely restricted it. ${ }^{20}$

14 For discussion summarizing the arguments for and against this rationale and several others see Beaney, supra note 5 , at 239-40.

15 See, e.g., Channel v. United States, 285 F.2d 217 (9th Cir. 1960); United States v. Dornblut, 261 F.2d 949 (2d Cir. 1958); Woodard v. United States, 254 F.2d 312 (D.C. Cir. 1958); Judd v. United States, 190 F.2d 649 (D.C. Cir. 195I).

16 "A defendant cannot claim that his constitutional rights were invaded when an entry and search of his premises was made with his consent and there is no evidence of force or coercion." Milyonico v. United States, 53 F.2d 937, 938 (7th Cir. 1931). Accord, United States v. Ziemer, 291 F.2d 100 (7th Cir.), cert. denied, 368 U.S. 877 (1961).

Since courts, e.g., Amos v. United States, 255 U.S. 313 (1921), and commentators, e.g., Note, Effective Consent to Search and Seizure, 113 U. PA. L. REv. 260 (1964), speak of consent to search as a "waiver" of fourth amendment rights, the right referred to as being waived can only be the right to be free from a warrantless police search.

17 It is evident that the great majority of consent searches are undertaken in relatively non-urgent contexts, in contrast, at least theoretically, to the settings within which searches grounded on the other two exceptions are carried out.

18 Cf. Johnson v. Zerbst, 304 U.S. 458, 464 (1938).

19 The federal courts have been especially strict in demanding that the prosecution show with clear and convincing evidence that the consent was unaccompanied by any coercion or duress. See Channel v. United States, 285 F.2d 217 (9th Cir. 1960); Judd v. United States, 190 F.2d 649 (D.C. Cir. 1951); United States v. Alberti, 120 F. Supp. 121 (S.D.N.Y. 1954); United States v. Novero, 58 F. Supp. 275 (D.D.C. 1954). The consenting individual must be informed of the constitutional rights he is waiving. Nusslein v. United States, 115 F.2d 690 (D.C. Cir. 1940); United States v. Festa, 192 F. Supp. 160 (D. Mass. 1960). Courts are quick to indulge a presumption of duress when the defendant consented while in police custody. See, e.g., Judd v. United States, 190 F.2d 649 (D.C. Cir. 1951); United States v. Wallace, 160 F. Supp. 859 (D.D.C. 1958). A failure to object is not in

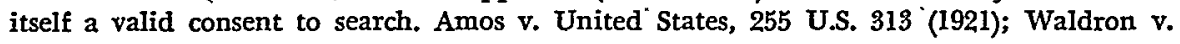
United States, 219 F.2d 37 (D.C. Cir. 1955). See generally Note, supra note 16, 113 U. PA. L. REv. 260.

20 See, e.g., Judd v. United States, 190 F.2d 649, 651 (D.C. Cir. 1951): "His statements while in jail, which are relied on as consent, may be summarized as: $I$ have nothing to hide, you can go there and see for yourself. Conceivably, that is the calm statement of an innocent man; conceivably again, it is but the false bravado of the small time criminal. But however it be characterized, it hardly establishes willing agreement that the officers search the household without first procuring a warrant." 
It is therefore anomalous that the great majority of decisions on the propriety of third party consent have not reflected this restrictive view. At first it might appear that what is essentially a vicarious waiver of a personal constitutional right ought never to be sanctioned, especially in light of the rationale generally underlying the consent exception. ${ }^{21}$ However, courts have fairly consistently upheld searches authorized by a third party when that party has exercised "sufficient control" over that which was searched or seized. ${ }^{22}$

Two distinct lines of reasoning underlie these decisions. The first, based on agency principles, allows the finding that the third party acts as the agent of the accused and is thus empowered to waive the latter's constitutional rights. The more common view is simply that the consenting party acts on his own behalf and waives his own rights by consenting to a search; the fact that the consent concurrently waives the constitutional protections of others is a consequence the force of which is apparently insufficient to proscribe the search.

\section{Implied Consent and Apparent Authority}

The agency theory of implied consent requires the court to infer from other facts in the case that the implicated party had authorized the third party to consent to a police search. Typical of this approach is United States $v$. Eldridge, ${ }^{23}$ where the defendant loaned his automobile to an individual who subsequently consented to its search by the police. The court held that because the defendant had given the consenting party control of the car and the keys to its trunk, he had delegated authority to the latter to consent to its search despite evidence indicating that the loan was for a short period of time and a specific purpose. ${ }^{24}$

Use of the rhetoric of agency, as illustrated by Eldridge, raises more

21 Some commentators have stated categorically that since fourth amendment rights are personal, they can be waived only by the individual for whose benefit they are intended. See Cornelius, Search and Seizure 72 (2d ed. 1930); Gross, Privacy-Its Legat Protection 76 (1964); Sobel, Current Problems in the Law of Search and Seizure 130 (1964).

22 The Supreme Court has never ruled upon this question. In Amos v. United States, 255 U.S. 313 (1921), the Court expressly avoided deciding whether a wife's consent could waive the rights of her husband. The decision for the defendant turned on the Court's inference from the circumstances of the search that the wife's consent had been coerced. Since then the Court has steadfastly refused to grant certiorari in such a case. For the Court's most recent rejections see Maxwell v. Stephens, 348 F.2d 325 (8th Cir. 1965), cert. denied, 382 U.S. 944 (1966); Burge v. United States, 342 F.2d 408 (9th Cir.), cert. denied, 382 U.S. 829 (1965). But cf. Stoner v. California, 376 U.S. 483 (1964).

23302 F.2d 463 (4th Cir. 1962).

24 But see State v. Bernius, 177 Ohio St. 155, 203 N.E.2d 241 (1964). 
significant questions than it puts to rest. A cursory review of agency principles shows that they are generally inapplicable to the situations within which most search and seizure issues arise. For example, agency relationships do not exist between the various residents of a dwelling simply because they live together. To be an agent one must have been appointed by the principal and be subject to his orders; ${ }^{25}$ the basis of the relationship is an agreement between the parties, ${ }^{26}$ and although that agreement may be an implied one, its existence must nonetheless be supported by sufficient evidence. Agency will generally not be implied unless the alleged agent has been permitted to perform similar acts or undertake a similar course of dealings in the past. ${ }^{27}$ Thus, for courts to hold an authorization binding in many third party consent circumstances, not only the authority to consent but also the requisite agency relationship must be inferred from facts which usually do not support such an inference. It is probably for this reason that several recent decisions have expressly rejected the agency theory. ${ }^{28}$ In Stoner v. California, ${ }^{29}$ the United States Supreme Court spoke out strongly against the use of agency fictions in cases involving the waiver of fourth amendment rights. In reversing the California court's holding that the consent of a hotel desk clerk properly authorized the police to search the defendant's room in the hotel, the Court stated: "Our decisions make clear that the rights protected by the Fourth Amendment are not to be eroded by strained applications of the law of agency or by unrealistic doctrines of 'apparent authority." "30

While the particular fiction overturned by the Stoner decision was more "strained" than that encountered in the more frequent spousal or joint tenant consent cases, the Court's admonition seems nonetheless applicable to the latter situations. The power of a wife or a roommate to consent to searches which necessarily invade the privacy of persons who have not consented stems, if at all, from their possession and control of the searched premises rather than from the usually un-

25 See Restatement, Agency $\$ \$ 1,15$ (1933).

26 Ibid. See, e.g., Quinn v. Phipps, 93 Fla. 805, 113 So. 419 (1927) (concurring opinion); Barnes v. Royer, 249 App. Div. 877, 292 N.Y.S. 469 (1937).

27 Restatement, Agency \& 15 (1933). See Weller v. Speet, 275 Mich. 655, 267 N.W. 758 (1936); Frank v. Board of Education, 90 N.J.L. 273, 100 Atl. 211 (1917). Agency does not arise by virtue of the marriage relationship. Restatenrent, AGENCY § 22; see Meyer v. Frenkil, 116 Md. 411, 82 Atl. 208 (1911); Harris v. Smith, 79 Mich. 54, 44 N.W. 169 (1889). The power of a wife to bind her husband for necessaries which have been furnished is properly based on principles of restitution, not of agency.

28 See, e.g., Roberts v. United States, 332 F.2d 892, 896 (8th Cir. 1964), cert. denied, 380 U.S. 980 (1965); People v. Perroni, 14 Ill. 2d 581, 590, 153 N.E.2d 578, 582 (1958).

29376 U.S. 483 (1964).

$30 \mathrm{Id}$. at 488 . 
warranted conclusion that the consenter is an agent of the ultimately implicated party.

A closely related doctrine that has occasionally been employed to validate third party consents to search is that of apparent or ostensible authority. When a person induces a third party to rely upon the appearance of agency authority in another, he is bound by the actions of his "agent" when the relying party would otherwise suffer loss.31 Although an actual agency relationship is not required for apparent authority to be operative, ${ }^{32}$ it is necessary to show conduct on the part of the "principal" which reasonably led the third party to believe that the agent possessed authority embracing the particular act in question. ${ }^{\mathbf{3 3}}$ It would seem that at least in cases involving searches of residences, an inference of apparent authority in the consenting party is unwarranted. The fact that several persons share a common residence should not be a sufficient basis for finding that each has apparent authority to consent to searches on behalf of the others. A more fundamental objection to the employment of the doctrine in the search and seizure context is that its reason for existence-to prevent a commercial loss from falling on an innocent party-seems particularly alien to criminal law issues, especially those involving the waiver of rights. Despite the fact that the state does suffer a "loss," in the sense that it might not be able to use the seized evidence against the non-consenting party, if courts seriously " indulge every reasonable presumption against waiver' of fundamental constitutional rights," 34 the mere appearance of authority to consent in a third person would appear to be an insufficient ground for a waiver of another's fourth amendment rights. ${ }^{35}$

In some situations, however, the consenter is in fact the agent of the implicated party. These cases arise most frequently in business

31 See, e.g., Masuda v. Kawasaki Dockyard Co., 328 F.2d 662 (2d Cir. 1964); Windsor Steel Products, Ltd. v. Whizzer Indus. Inc., 157 F. Supp. 284, 288 (E.D. Mich. 1957), aff'd, 261 F.2d 837 (6th Cir. 1958); Lange v. Curtin, 11 Cal. App. 2d 161, 53 P.2d 185 (1936).

32 See, e.g., Anheuser Busch v. Grovier-Starr Produce Co., 128 F.2d 146, 152 (10th Cir. 1942); Petersen v. Kuhn, 110 Neb. 372, 193 N.W. 756 (1923).

33 See cases cited note 31 supra.

34 Johnson v. Zerbst, 304 U.S. 458, 464 (1938).

35 California courts have for years employed a form of the apparent authority doctrine. Searches and seizures have been held reasonable if the consenter believed he had the authority to consent and if the police searchers believed the consenter had such authority. By hinging the reasonableness of a search on the subjective beliefs of the consenter and the police searchers, a premium is placed on mistake and unawareness. The leading example of this doctrine is People v. Gorg, 45 Cal. 2d 776, 291 P.2d 469 (1955). The recent United States Supreme Court decision in Stoner v. California, 376 U.S. 483 (1964), reversing a California judgment based on the apparent authority doctrine which had upheld the consent of a hotel desk clerk to a police search of a patron's room, casts considerable doubt on the future of the California doctrine of apparent authority. 
contexts, as when a clerk consents to a search of an office ${ }^{36}$ or when an office manager consents to an inspection of a firm's records. ${ }^{37}$ In such cases the essential question appears to be whether the scope of the agent's actual authority includes the right to permit a police search of that over which the agent is exercising control. When the agent's powers are general and the principal has entrusted him with significant duties, it is not unreasonable to assume that the agent is empowered to deal with the police as his judgment may direct. Thus, in United States $v$. Antonelli Fireworks Co., ${ }^{38}$ the court's decision that the office manager had implied authority to permit the police to inspect the company's records was justifiable in light of the manager's broad supervisory powers over the records. However, when the agent's authority is more limited, power to consent to a search should not be inferred. In Lord $v$. Kelley, ${ }^{39}$ the court correctly held that the tax records released to an Internal Revenue agent by the defendant's accountant could not be used in criminal proceedings against him because the accountant's action in releasing the records was "beyond the scope of [his] actual or apparent authority." 40

The several agency rationales employed to sanction third party consents to search are in most cases inadequate to justify the decisions. Usually the consenter in no sense acts as the agent of the accused. Furthermore, when the consenting party does act on behalf of the implicated party, as in the cases involving searches of business premises, only a general agent with broad powers can realistically be viewed as having sufficient authority to consent to a search on behalf of his principal.

\section{The Possession and Gontrol Rule}

The rule most commonly employed to uphold third party consents to search is that one who has possession and control of premises or an object may consent to its search and evidence uncovered by that search may be used against anyone. ${ }^{41}$ This rule focuses the court's at-

36 See, e.g., United States v. Block, 202 F. Supp. 705 (S.D.N.Y. 1962); Hays v. State, 38 Okla. Crim. 331, 261 Pac. 232 (1927).

37 See, e.g., United States v. Antonelli Fireworks Co., 155 F.2d 631 (2d Cir.), cert. denied, 329 U.S. 742 (1946).

38 Ibid.

39223 F. Supp. 684 (D. Mass. 1963), appeal dismissed, 334 F.2d 742 (1st Cir. 1964), cert. denied, 379 U.S. 961 (1965). Accord, Hinchcliff v. Clarke, 230 F. Supp. 91 (N.D. Ohio 1963).

40223 F. Supp. at 690.

41 See, e.g., United States v. Sferas, 210 F.2d 69 (7th Cir. 1954) (consent of business partner binding on other partner); People v. Perroni, 14 Ill. 2d 581, 153 N.E.2d 578 
tention solely on the consenter's relationship to the searched premises. ${ }^{42}$ Within this framework a comprehensive set of rules to govern third party consents to search has been built.

It has consistently been held that consent by one who has no right to possession and control of premises does not render the search of those premises reasonable and that evidence uncovered by such a search should be excluded. A landlord cannot consent to a search of his tenant's apartment ${ }^{43}$ and a hotelkeeper cannot consent to a search of his patron's room. ${ }^{44}$ Similarly when the consenting party has less than a complete proprietary or possessory interest in the searched premises, the implicated party is usually not bound by the consent. Thus, in Reeves v. Warden, Maryland Penitentiary, ${ }^{45}$ the Fourth Circuit held that the defendant's mother, who, with the defendant, lived in the home of a relative, was "without authority" to consent to a police search of defendant's room. Likewise, in People $v$. Jennings, a California court held that a daughter could not consent to a search of her father's home.

When several persons have co-equal rights to the possession and control of premises, the prevailing rule is that any one of them may give consent to a search and the evidence thus disclosed may be used against anyone. ${ }^{47}$ The typical situation is a wife's consent to a search that incriminates her husband..$^{48}$ Such searches invariably are defended on the ground that since consent was given by an individual with possession and control, the search was reasonable; rarely raised is the question of the vicarious waiver of the husband's rights. The problem

(1958) (wife's consent binding on husband). Commentators generally accept this position: "any person having a sufficient level of control over a dwelling should be able to consent to a search of it." Note, supra note 16, 113 U. PA. L. Rev. at 273; see Note, 36 TEMP. L.Q. 95 (1962). But see Comment, supra note 3, 69 Dick. L. REv. 69 (1964).

42 This focus is illustrated in the way courts frame the issue. See, e.g., Roberts v. United States, 392 F.2d 892, 896-97 (8th Cir. 1964): "This is a question of the wife's own rights to authorize entry into premises where she lives and of which she had control." People v. Shambley, 4 Ill. 2d 38, 43, 122 N.E.2d 172, 174 (1954): "It is clear that in giving her consent she ... was acting in her own right as occupant of the premises."

43 E.g., Chapman v. United States, 365 U.S. 610 (1961); State v. Scrotsky, 39 N.J. 410, 189 A.2d 23 (1963).

44 E.g., Louden v. Utah, 379 U.S. 1 (1964), reversing per curiam, 15 Utah 2d 64, 387 P.2d 240 (1963); Stoner v. California, 376 U.S. 483 (1964).

45346 F.2d 915 (4th Cir. 1965).

46142 Cal. App. 2d 160, 298 P.2d 56 (1956). Cf. State v. Bernius, 177 Ohio St. 155, 203 N.E.2d 241 (1964).

47 United States v. Sferas, 210 F.2d 69 (7th Cir. 1954) (consent of business partner binding on other partner); People v. Shambley, 4 Ill. 2d 38, 122 N.E.2d 172 (1954) (wife's consent binding on husband).

48 E.g., Sergio v. United States, 21 F. Supp. 553 (E.D.N.Y. 1937); People v. Perroni, 14 Ill. 2d 581, 153 N.E.2d 578 (1958). 
is not limited to cases involving spousal consent. In People v. Banks, ${ }^{49}$ the defendant's roommate permitted the police to search their room, and a California court held that an authorization by a joint occupant constituted a "sufficient justification for entry and search by the officers." 50

When the possessory interest of the consenter is both proprietary and greater than that of the nonconsenter, the consent is usually held binding. In Burge $v$. United States, ${ }^{51}$ the Ninth Circuit held that the consent of a lessee of an apartment waived her temporary guest's right of privacy. ${ }^{52}$ The Supreme Court of Minnesota recently held that a father's consent to a search of his twenty-two year old son's room in the family home rendered the search constitutionally unobjectionable. ${ }^{53}$

Several courts have modified the impact of the possession and control rule by holding valid a search and seizure consented to by a third party only when that party has exercised possession and control over the particular area where the evidence was seized or over the object

4947 Cal. Rptr. 499 (Dist. Ct. App. 1965).

$50 \mathrm{Id}$. at 500. But cf. Tompkins v. Superior Court, $59 \mathrm{Cal}$. 2d 65, 378 P.2d 113, $27 \mathrm{Cal}$. Rptr. 889 (1963).

51342 F.2d 408 (9th Gir.), cert. denied, 382 U.S. 829 (1965). But cf. United States v. Blok, 188 F.2d 1019 (D.C. Cir. 1950); Idol v. State, 233 Ind. 307, 119 N.E.2d 428 (1954).

52 A "house-guest" is entitled to a fourth amendment right of privacy in premises in which he is residing. However, such has not always been the rule. Prior to the Supreme Court decision in Jones v. United States, 362 U.S. 257 (1960), lower federal courts usually held that individuals had no fourth amendment right of privacy unless they could show a proprietary or possessory interest in the premises searched. See, e.g., United States v. Pepe, 247 F.2d 838 (2d Cir. 1957); United States v. Chieppa, 241 F.2d 635 (2d Cir.), cert. denied sub nom. Ivicola v. United States, 353 U.S. 973 (1957); Gaskins v. United States, 218 F.2d 47 (D.C. Cir. 1955); United States v. Eversole, 209 F.2d 766 (7th Cir. 1954); Grainger v. United States, 158 F.2d 236 (4th Cir. 1946); Gibson v. United States, 149 F.2d 381, cert. denied sub nom. O'Kelley v. United States, 326 U.S. 724 (1945); In re Nassatta, 125 F.2d 924 (2d Cir. 1942). In Jones, the Court considerably broadened the scope of the fourth amendment protection by discarding limiting property doctrines and by holding that anyone "legitimately on the premises" belongs to the class for whose sake the constitutional protection is given. 362 U.S. at 267. The meaning of the Jones rule has not been clearly settled. Compare Note, The Exclusionary Rule and the Question of Standing, 50 GEO. L.J. 585 (1962) with Weeks, Standing To Object in the Field of Search and Seizure, 6 ARIz. L. REv. 65 (1964). However, post-Jones decisions have consistently indicated that, at the least, anyone residing in a dwelling, including a guest, is protected by the same fourth amendment right of privacy previously afforded only the traditional classes of proprietors. For discussions of the fourth amendment rights of temporary occupants see Wion v. United States, 325 F.2d 420 (10th Cir. 1963); Walker v. Peppersack, 316 F.2d 119 (4th Cir. 1963); United States v. Warden, Rikers Island Penitentiary, 240 F. Supp. 486 (S.D.N.Y. 1965); United States v. Blitz, 199 F. Supp. 326 (E.D.N.Y. 1961).

53 State v. Kindermann, 271 Minn. 408, 136 N.W.2d 577 (1965). Accord, Maxwell v. Stephens, 348 F.2d 325 (8th Cir.), cert. denied, 382 U.S. 944 (1965). 
actually seized. In State v. Evans, ${ }^{54}$ the Supreme Court of Hawaii held that a wife who occupied the home jointly with her husband could not consent to a search which disclosed stolen jewelry hidden in her husband's cufflink case in his bureau drawer. A similar result was reached in Holzhey $v$. United States, ${ }^{55}$ where the Fifth Gircuit held that the defendant's daughter, who owned the premises where the defendant resided, could not consent to a search of the latter's locked personal belongings, notwithstanding the fact that these belongings were located in an area over which the daughter exercised possession and control. ${ }^{56}$

The possession and control rule serves a useful function in separating out those persons who ought never to be permitted to consent to a search. It is clear, for example, that a complete stranger cannot properly authorize the search of one's home. However, beyond this purely negative function the efficacy of the formula becomes doubtful; the rule is inadequate as a yardstick for determining the propriety of third party consents to search chiefly because in operation it omits consideration of interests of all persons other than the consenter. One with possession and control of a dwelling is, of course, entitled to all the powers that usually flow from such control and normally this would include the power to authorize a police search. However, where others are entitled to constitutional protections in the same areas, it is not clear that the consenter's power should be permitted to be exercised freely at the expense of the rights of these others. The rule itself, without more, does not provide an adequate explanation as to why the consent of one person should dispel the protection due another.

One explanation of the possession and control rule which would justify its blanket application in third party consent cases is that the term "houses" in the fourth amendment relates primarily to the protection of a property right ${ }^{57}$ rather than a right of privacy. The pro-

5445 Hawaii 622,372 P.2d 365 (1962).

55 223 F.2d 823 (5th Cir. 1955). See Maxwell v. Stephens, supra note 53, at 338 (dissenting opinion).

56 This modified rule takes considerably more cognizance of interests of persons other than the consenter than does its broader counterpart. Its principal inadequacy stems from its need to demarcate with some precision particular areas of possession and control. Should a wife be permitted to consent to a search of her husband's half of the bedroom closet, used mainly by the husband but in which the wife occasionally places her things and which she regularly cleans? The administration of such a rule would prove awkward for both the courts and the police, to whom it would provide a minimum of guidance. Furthermore, even if the area is clearly defined as one over which the consenter has possession and control, this should not necessarily be sufficient to validate every third party consent search. See text accompanying notes 57-82 infra.

57 See Note, Effective Consent to Search and Seizure, 113 U. PA. L. REv. 260, 273 (1964). 
tection thus afforded aims at barring official trespasses. It follows from this view that any person whose consent would obviate the possibility of trespass could give valid permission to enter and search.

Although there seem to be no decisions directly construing the "houses" terminology of the fourth amendment, a number of factors suggest that while the fourth amendment certainly is aimed at protecting property rights ${ }^{58}$ and inhibiting police trespasses, its protections extend a great deal further. The language consistently used by the Supreme Court indicates that at the core of the amendment's protection is the personal right ${ }^{59}$ to be free from arbitrary police intrusions into one's privacy. ${ }^{60}$ This right extends beyond the aged borders of property and trespass law; ${ }^{61}$ although an unreasonable search must involve a physical intrusion into a protected space, $^{62}$ that intrusion need not constitute a trespass to contravene the amendment. ${ }^{63}$ If it were otherwise, the police would be permitted to search premises simply upon gaining legal entrance; this of course is not the law. The fourth amendment protection against unreasonable searches and seizures is quite clearly a matter distinct from the legality of the searching officer's presence on the premises. ${ }^{64}$

58 See Boyd v. United States, 116 U.S. 616, 630 (1886).

59 The personal nature of the right is emphasized most frequently in the cases involving an individual's standing to invoke the exclusionary rule. In order to have standing to complain of an unreasonable search and seizure, the complainant must allege that the search violated his personal rights. See note 52 supra, and cases cited therein.

60 The most recent sample of this language is found in Schmerber v. California, 86 Sup. C.t 1826, 1834 (1966): "The overriding function of the Fourth Amendment is to protect personal privacy and dignity against unwarranted intrusion by the State. In Wolf we recognized ' $[t]$ he security of one's privacy against arbitrary intrusion by the police' as being 'at the core of the Fourth Amendment' and 'basic to a free society.' 338 U.S. at 27. We reaffirmed that broad view of the Amendment's purpose in applying the federal exclusionary rule to the States in Mapp." See Mapp v. Ohio, 367 U.S. 643 (1961).

61 For discussion of the relationship between the law of trespass and property and the fourth amendment see Comment, Search and Seizure in the Supreme Court: Shadows on the Fourth Amendment, 28 U. CHr. L. REv. 664, 667-77 (1961).

62 Maguire, Evidence of Guilt 188 (1959).

63 For instances where searches violated fourth amendment rights but could not support actions in trespass, see Wion v. United States, 325 F.2d 420 (10th Cir. 1963); Walker v. Peppersack, 316 F.2d 119 (4th Cir. 1963); United States v. Warden, Rikers Island Penitentiary, 240 F. Supp. 486 (S.D.N.Y. 1965); United States v. Blitz, 199 F. Supp. 326 (E.D.N.Y. 1961). Each of these cases held that the constitutional rights of the defendants involved could have been infringed by police searches of premises upon which they were only temporarily located. However, because of their lack of proprietary or possessory interests in the searched premises, it is doubtful whether any of the defendants could have maintained an action in trespass. For discussion of the interest necessary to support an action in trespass see MARTz, RIGHTS INCIDENT to THE POSSESSION OF LAND 36-40 (1954).

64 This point was stated by Mr. Justice Frankfurter in his dissent in Harris v. United States, 331 U.S. 145 (1947), which involved the permissible scope of a search incident to 
Also tending to undermine the conclusion that the fourth amendment primarily protects a property right are the requirements relating to a person's standing to object to an allegedly unconstitutional search and seizure. ${ }^{65}$ In Jones $v$. United States, ${ }^{68}$ the Supreme Court held that an individual who was merely "legitimately on the premises" had standing to object to the search and seizure which led to his conviction, thus impliedly broadening the protected class to include persons without property interests in the searched premises. Speaking through $\mathrm{Mr}$. Justice Frankfurter the Court said:

[I]t is unnecessary and ill advised to import into the law surrounding the constitutional right to be free from unreasonable searches and seizures subtle distinctions, developed and refined by the common law in evolving the body of private property law which, more than almost any other branch of the law, has been shaped by distinctions whose validity is largely historical. ${ }^{67}$

By providing fourth amendment protections to a class which has no property interests to protect, the Jones case plainly underscored the position that the amendment protects a sphere of privacy extending beyond the limits of one's private property interests.

It is perhaps because of the weakness of the argument that the fourth amendment is aimed mainly at protecting property rights that most courts have neither relied on, nor even offered, such a view. Rather, decisions have frequently been based on common law property notions relating to the "right" of an owner or a proprietor to permit the police to enter and search his premises. This appealing line of argument was employed in two recent cases. In Burge v. United States, ${ }^{68}$ where the lessee of an apartment consented, while in police custody,

a valid arrest: "Much is made of the fact that the entry was lawful. But we are not confined to issues of trespass. The protection of the Fourth Amendment extends to improper searches and seizures quite apart from the legality of an entry." 331 U.S. at 164. Even where the police are on premises pursuant to a valid search warrant, the officers' conduct in carrying out the search may be so unreasonable as to invalidate the search. See Kremen v. United States, 353 U.S. 346 (1957) (police removal of entire contents of searched cabin held unreasonable).

65 See notes 52 \& 59 supra.

66362 U.S. 257 (1960).

67 Id. at 266.

68342 F.2d 408 (9th Cir.), cert. denied, 382 U.S. 829 (1965), reversing 333 F.2d 210 (9th Cir. 1964). Evidence taken from a bathroom cabinet used jointly by the lessee and her guest was introduced at the latter's trial. The Ninth Circuit originally held that the evidence taken from the cabinet could not be used in criminal proceedings against the guest, Burge v. United States, 333 F.2d 210 (9th Cir. 1964), but reversed itself on rehearing, Burge v. United States, 342, F.2d 408 (9th Cir.), cert. denied, 382 U.S. 829 (1965). 
to a search that implicated her,temporary guest, the Ninth Circuit posed the issue somewhat emotionally: "Does the Constitution say that this lady may lawfully consent to the entrance into her bathroom of any person in the whole wide world except officers of the government whose duty it is to enforce that government's laws?"69 Similarly, but more calmly, the Supreme Court of Minnesota in State v. Kinder$m a n n^{70}$ stated that since a father's rights are superior to those of the children who live in his home, the constitutional protection afforded the child (who in this case was twenty-two years old) had to be "viewed in light of the father's right to waive it."'71

The position taken by these courts is compelling in its simplicity. The ownership of private property includes the right to complete control of activities and objects on the premises. It is therefore difficult to avoid the conclusion that these rights of control include an almost inviolable right to invite the police to search the premises. Posing the basic issue in this manner suggests that the tension in third party consent cases is caused not by a conflict between individual rights of privacy and the needs of state law enforcement but rather by a conflict between privacy and property rights.

A superficially attractive solution to this conflict would be to hold consent searches reasonable only as to those persons who actually consented to them. Anyone could thus consent to a search of premises over which he exercised sufficient possession and control; evidence uncovered would simply be excluded as to any residents whose consent was not obtained. However, the solution actually solves nothing because it does not protect the nonconsenter's interest in privacy and runs directly counter to the rationale underlying the exclusionary rule; permitting $A$ to consent to a search that invades $B$ 's privacy and thereafter suppressing the evidence against $B$ does nothing to protect against the invasion of $B$ 's privacy. Moreover, the purpose of the exclusionary rule ${ }^{72}$ is not served by initially approving the search but thereafter holding it unreasonable and excluding the evidence with respect to those not consenting.

Rejection of this solution does not necessarily lead to the conclusion that the third party should always be permitted to authorize a search. For several reasons it appears that the balance of competing interests

69342 F.2d at 413.

70271 Minn. 405, 136 N.W.2d 577 (1965).

$71 \mathrm{Id}$. at 410,136 N.W.2d at 580 .

72 The purpose of the exclusionary rule is not to assuage the violation of an individual's personal rights but to deter unreasonable police conduct. Linkletter v. Walker, 381 U.S. 618 (1965); Mapp v. Ohio, 367 U.S. 643 (1961); Wolf v. Colorado, 338 U.S. 25 (1949). 
should not be struck in favor of protecting the asserted property rights of the consenter. First, the property right argument has force only in those cases where the consenter is an owner or proprietor and the implicated party - a temporary guest, for example, or a child-has a lesser interest. Whenever the parties have equal proprietary interests, as do joint tenants and spouses, it would seem that each person's powers should be limited by the rights of those with whom the privacy is shared. In Tompkins $v$. Superior Court, ${ }^{73}$ a police search consented to by one tenant and carried out over the objection of another who was present, was held unreasonable by the California Supreme Court. In its opinion the court stated: "A joint occupant's right of privacy is not completely at the mercy of another with whom he shares legal possession." 74 While in that case the implicated party was able to voice his objection to the search while it was being conducted, the court's reasoning would seem to be equally applicable to the great majority of cases in which the implicated party is unable, because of his absence, to make known his objection until after the search is completed. The right of privacy ought not to depend on so fortuitous a circumstance as a person's presence on the searched premises. A post-search objection should be given the same weight as one registered before the search was undertaken.

Second, even when the consenting party has a greater proprietary interest in the premises than does the implicated party, it is quite unrealistic to characterize the consent as the assertion of a property right. It is rare that the consenter affirmatively desires his premises to be searched by police officers. ${ }^{75}$ It would appear that in the great majority of consensual searches the consenter is indifferent or acquiescent. Such an attitude is far removed from that vividly portrayed in the Burge decision; ${ }^{76}$ its prevalence reduces the importance of the asserted conflict between the nonconsenter's interest in privacy and the consenter's property rights, and may question even the existence of such a conflict. If the consenter is not actually demanding or even requesting that his house be searched, must the consent conflict with the nonconsenter's interests? It appears that it does not and that the police, by postponing their search until the consent of all affected parties is obtained, might easily dispel any possibility of conflict. ${ }^{77}$

7359 Cal. 2d 65, 378 P.2d 113, 27 Cal. Rptr. 889 (1963).

74 Id. at 69,378 P.2d at 116,27 Cal. Rptr. at 892.

75 See Note, supra note 57 , at 260.

70 For a more pointed statement of this position, see the dissenting opinion in the court's earlier disposition of the case. Burge v. United States, 333 F.2d 210, 219-21 (9th Cir. 1964).

77 Of course, when the owner demands or requests that the police search, the conflict 
It can now be suggested that a proper solution to the third party consent problem would require personal consent by the implicated party before the evidence obtained could be used against him. In positive terms, such a rule would require that the police obtain the consent of all parties whose privacy a proposed search would invade before conducting the search. ${ }^{78}$

A solution requiring such individual consent is, of course, not free from difficulty. It would not completely resolve the problems posed in those cases when the consenting party affirmatively requests the police to search his premises. ${ }^{79}$ Moreover, the difficulties presented when the object searched is personalty rather than a dwelling are not completely obviated by such a rule. These cases arise when the implicated party has given the consenting party possession of an object such as an automobile or a briefcase. ${ }^{80}$

Another problem may arise from a rule requiring the consent of every party whose privacy a particular search would invade. If $A$ consents to a search that incriminates him can he thereafter object to the search on the ground that it was unreasonable because $B$ 's consent was not obtained? In such a circumstance, it would appear that $A$ 's consent will at least make the search reasonable as to him; since he consented, his personal rights were not violated by the search. ${ }^{81}$ Moreover, practically all jurisdictions would not permit $A$ to object to a search on the ground that it violated the rights of another. ${ }^{82}$ California appears to be the only jurisdiction that gives an individual standing to object to a search that violated another's rights. ${ }^{83}$ However, although the consenter may be given standing to object to the search, it does not follow

is extant. For a case where the police were so called upon to search see Woodard v. United States, 254 F.2d 312 (D.C. Cir.), cert. denied, 357 U.S. 930 (1958).

78 Cf. United States v. Blok, 188 F.2d 1019 (D.C. Cir. 1951) (affirming suppression of evidence taken from the defendant's desk pursuant to a search consented to by her employer); Idol v. State, 233 Ind. 307, 119 N.E.2d 428 (1954) (caretaker of a garage who permitted the defendant to store his automobile in it could not validly consent to a search of the garage and an examination of the defendant's automobile).

79 See Woodard v. United States, supra note 77. Even in the cases where the proprietor requests a police search it is not clear that the search ought to be made without the consent of others whose privacy will be invaded or without a warrant. Perhaps a proper solution to this problem can be found in the nature of the relationships between the concerned parties themselves, and between the concerned parties and the searched premises. For example, it might be more appropriate to allow the search where the nonconsenting party is merely a weekend guest than where he is a permanent resident.

80 See, e.g., Sartain v. United States, 303 F.2d 859 (9th Cir.), cert. denied, 371 U.S. 894 (1962); United States v. Eldridge, 302 F.2d 463 (4th Cir. 1962).

81 See note 16 supra.

82 See notes 59 and 52 supra.

83 E.g., People v. Martin, 45 Cal. 2d 755, 290 P.2d 855 (1955). 
that the evidence thus obtained must be suppressed. The consent in such a case may be taken as equivalent to a general waiver of any objection to the search and treated like an untimely objection. While this position is not completely consistent with the rationale underlying California's standing rule, it appears more acceptable than the alternative, which permits an individual to contest the reasonableness of a search after he has freely and intelligently consented to it, and thereby to gamble on its outcome.

\section{Conclusion}

The rule proposed in this comment, if given effect, will have a somewhat restrictive effect on police power to search. That the police are restricted, however, does not seem to be a particularly compelling objection to the proposal. If the required consenters cannot be found or will not consent, the ready alternative is the searci warrant. It should be recalled that all consent searches are non-urgent exceptions to the warrant requirement, ${ }^{84}$ and that courts continually extol the desirability of requiring officers to seek a warrant before conducting a search. ${ }^{85}$ Therefore, it does not seem to impose too serious a burden on the police to require that they secure a warrant when the consent of all persons who are to be searched cannot be obtained. The consequences of such a requirement ought neither to impede effective enforcement of the law nor adversely affect an orderly society.

84 See text accompanying notes 15-20 supra.

85 E.g., Mr. Justice Jackson's statement in Johnson v. United States, 333 U.S. 10 (1948): "The point of the Fourth Amendment, which often is not grasped by zealous officers, is not that it denies law enforcement the support of the usual inferences which reasonable men draw from evidence. Its protection consists in requiring that those inferences be drawn by a neutral and detached magistrate instead of being judged by the officer engaged in the often competitive enterprise of ferreting out crime .... When the right of privacy must reasonably yield to the right of search is, as a rule, to be decided by a judicial officer, not by a policeman or government enforcement agent." Id. at 13-14. 